\title{
Discussion about Conceptual Framework
}

\author{
Huijuan $\operatorname{Lin}^{1}$ \\ ${ }^{1}$ Beijing Institute of Technology Zhuhai Campus, China \\ Correspondence: Huijuan Lin, School of Accounting and Finance, Beijing Institute of Technology Zhuhai \\ Campus, China. E-mail: taro_930@126.com
}

Received: March 14, 2015

Accepted: April 2, 2015

Online Published: May 25, 2015

doi:10.5539/ibr.v8n6p191

URL: http://dx.doi.org/10.5539/ibr.v8n6p191

\begin{abstract}
Standard setters and most academics maintain that accounting standards ought to rest on a set of guiding principles stated explicitly in a "conceptual framework." The FASB and IASB are currently involved in a project to refine conceptual framework documents developed earlier. At this point, it is not clear what their final product will look like; its defining characteristics as well as the substantive content can only be surmised. This paper addresses the issues that FASB and IASB face, including the question of what a conceptual framework should be all about. First, the paper describes and illustrates the current conceptual framework and the attitude of FASB and IASB. Second, the paper suggests characteristics that a conceptual framework ought to exhibit. Most of these suggestions are based on our critique of the existing framework and the FASB-IASB work in progress.
\end{abstract}

Keywords: conceptual framework, IASB, FASB, revaluation

\section{Introduction}

In recent years, since heated debate is on about how to develop the conceptual frameworks, this paper will concentrate on the development of conceptual frameworks which is built up a statement of generally accepted theoretical principles which form the frame of reference for a particular field of enquiry. Thus, this paper will be divided the development of conceptual frameworks into three sections. The first section will describe the FASB (Financial Accounting Standards Board) and IASB (International Accounting Standards Board)'s attitudes toward develop conceptual framework for accounting to act as an underpinning for their standard setting activities and show how the current accounting standards work which including the similarity and the differences between different regulatory bodies. Moreover, the paper will illustrate how the IASB/FASB chose income view for new conceptual framework and point out the relationship between concepts of valuation and economic income under the new IASB/FASB approach including the comparison of different evaluation systems and the effects of these systems on income. In the final section of this paper will discuss that does the various conceptual framework projects of measurement systems make better financial reporting by qualitative characteristics or not and explain how to disclose comprehensive income would make better financial report.

\section{Background of the Project}

\subsection{The IASB/FASB's Manner}

The two most influential standard-setters are the Financial Accounting Standards Board ("FASB") and the International Accounting Standards Board ("IASB"). The FASB develops standards for the United States, whereas the IASB sets rules for the whole world, particularly for the member states of the European Union.

According to FASB's view, in terms of how to develop the conceptual as an underpinning standard, they point out that an underpinning standard means the concepts and relationships that will underlie future financial accounting standards, and those which forms the foundations for existing standards, will be evaluated in the light of the conceptual framework. (FASB/IASB, 2005) Preparers of financial reports are expected to use the conceptual framework to guide them in their choices of solutions to their accounting problems. Users should gain from the project by increasing their understanding of financial information and of the declared goals which the FASB are seeking to achieve. Over the last decade the ASB and the IASC have developed conceptual frameworks that have many elements in common and both of these are undertaken by FASB' s work. Without an underpinning conceptual framework, the same theoretical issues are revisited on numerous occasions by different standard-setting working parties. One of the most important is that the accounting treatments of these working parties are inconsistent with each other and on some issues they have incompatible concept. Thus, they 
are going to develop an underpinning and agreed conceptual framework which should therefore be a theory of accounting against which practical problems can be tested objectively, the utility of which is decided by the adequacy of the practical solutions it provides (UK and International GAAP).

\subsection{Current Conceptual Framework}

However, this paragraph is going to describe the current conceptual framework developed by FASB and ASB individually. The first phase of FASB' conceptual framework was to develop the objectives of financial reporting. More specific, the primary objectives identified in the statement: "financial reporting should provide information that is useful to present and potential investors and creditors and other users in making rational investment, credit, and similar decisions". (FASB/IASB, 2005) People benefit from these kinds of useful information not only the direct users but also the indirect users including financial analysts and advisers, journalists, regulatory authorities and trade unions and so on. According to the second concepts statement-Qualitative Characteristics of Accounting Information (including the decision-makers, cost/benefit constraint, understandability, relevance and reliability, comparability, materiality and conservatism)-examines the characteristics that make accounting information useful to the users of that information. (UK and International GAAP) The following statement was focus on elements of financial statements. Finally, the statement was about recognition and measurement. On the other hand, as the ASB's conceptual framework is undertaken by FASB's conceptual framework, the differences in the circumstances of FASB and ASB are smaller than the similarities. The difference of opinion may be due to variations in temperament, education etc., between the two countries, or it might be due to the different needs and pressures faced by standard setters in a political regulatory environment versus those in a largely unregulated one. (Peasnell K Accounting and Business Research Autumn, 1982) In spite of current conceptual framework is comprehensive, the weakness of current conceptual framework project may be attributed to a numbers of factors. According to UK and International GAAP, the most significant reason will probably be failure to deal with the fundamental issues of recognition and measurement. (GAAP) More exactly, the current conceptual framework was stated recognition and chosen measurement by not determining income views. This shortcoming would lead to not providing useful information to users or providing misleading information to users. Thus they need to develop new conceptual framework by starting defined the income views. However, whether IASB/FASB actually achieves the objective of conceptual framework should be discussed in part three.

\section{The Development of New Conceptual Framework}

\subsection{IASB/FASB's New Conceptual Framework}

Since defining income is a beginning of developing conceptual framework but also might be the bedrock of the new conceptual framework, choosing the income view plays an important role in other components (recognition, definition, etc.). There are various views of income depending on different person's opinion. The two primary views of income are "revenue and expense view" which income is the difference between outputs from and inputs to the enterprise's earning activities during a period and "asset and liability view" which cited by Hicks that "grounded in a theory prevalent in economics: that an entity's income can be objectively determined from the change in its wealth plus what it consumed during a period". (Hicks, 1946) On this foundation that the conceptual primary of assets and the superiority of the "asset and liability view" (Hick No.1) over the "revenue and expense view" in measuring a firm's income, are purportedly based. (FASB/IASB, 2005) FASB/IASB was chosen Hicks No.1 income because they believed Income No.1 ex post is not a subjective affair, like other kinds of income; it is almost completely objective. (FASB/IASB, 2005) But, when using asset and liability view, they do not recognize all the assets which including tangible assets and intangible assets. At least, they do not recognize some parts of intangible assets such as $R \& D$ expense but these intangible assets have match the definition of assets. According to Bromwich and Kaldor, Hicks No.1 ex ante income will be based on what was expected about cash flows and interest rates at the beginning of the period, and ex post on what actually occurs during the period and on revised expectations about the future at the end of the period (Bromwich, 1992; Kaldaor, 1955). The ex post income came too late for the users to make decision but the ex post income can affect the next period ex ante income. So, the main problem with ex post income is that when calculating ex ante for the following year, how much expectation cash flow should take account from the previous year's ex post income. According to Penman, this is an empirical question, to which the answer may vary according to different types of business activities and how far 'permanent' and 'transitory' elements can be distinguished. (Penman, 2007); while also being subject to different users' needs and trade-offs of 'relevance' and 'reliability' (Sundem, 2007), which would be discuss in section three. However, although using Hicks No.1 income, different evaluation also cause different amount of income. 


\subsection{Impact of Revaluation System on Comprehensive Income}

Using different evaluation system including historical cost, fair value and deprival value to measure assets and liabilities cause different amount of changes of equity, which is comprehensive income. In terms of using historical cost, when revaluate the assets and liabilities, the value of assets and liabilities on balance sheet would not be change. Thus, since using historical cost cannot obtain Hicks No.1 income, it might not provide useful information about future cash flows to investors. Moreover, under the assumption of idealized complete perfect market equilibrium, using fair value to measure all the assets (intangibles and tangibles) and liabilities can attain Hicks No.1 income. However, Beaver and Demski (1979) have pointed out that, in a world of perfect and complete markets, accounting would not be required, because everybody would be fully informed, so that the very existence of accounting implies a degree of market imperfection. (Beaver \& Demski, 1979) Therefore, in reality, the selling price is mismatched the entry prices. In other words, it is very hard to estimate the fair value of the assets and liabilities and also when estimating fair value, it may introduce into measurement the subjective estimates of management. However, using current value to measure assets and liabilities can achieve Hicks No.1 income in two situations. Firstly, when current value equal to replacement cost and also equal to value in used which is the present value of future cash flows, using value in used to revaluate assets and liabilities cause the changes of equity which is Hicks No.1 income. Nevertheless, when current value equal to replacement cost but not equal to value in used, in this case, the change of equity is not the Hick No.1 income. According to It ought to adjust the replacement cost to value in used by adding value of some intangible assets such as brand name, some rights etc. Hence, it might bring about the subjective estimate of these intangible assets. Finally, since there are various measurement systems which would cause different amount of income, the measurement phase of the conceptual framework project is now focusing on identifying suitable measurement bases and developing guidance that explains how the objective of financial reporting and qualitative characteristics of financial reporting information apply to the selection of a measurement basis.

\section{Discussion about Better Financial Statement}

\subsection{Better or not Depends on User's Need}

As private bodies, the boards do not have the power to make their rules mandatory, so they have to convince potential users to prepare financial statements according to their standards, and policymakers to accept statements in accordance with them. According to proponents of International Financial Reporting Standards (IFRS) publicly traded companies must apply a single set of high quality accounting standards in order to contribute to better functioning capital markets (Quigley, 2007). Therefore, mandatory IFRS adoption has the potential to facilitate cross-border comparability, increase reporting transparency, decrease information costs, reduce information asymmetry, and thereby increase the liquidity, competitiveness, and efficiency of markets (Ball, 2006; Choi \& Meek, 2005). These potential benefits rely on the presumption that mandatory IFRS adoption provides superior information to market participants and/or increased accounting comparability compared to previous accounting regimes. However, there is little and often conflicting empirical evidence that this is the case. Moreover, while all of these potential benefits provide a persuasive argument for IFRS adoption, the costs associated with such a transition cannot be ignored. For example, Ball (2006) notes that the fair value orientation of IFRS could add volatility to financial statements. This volatility takes the form of both good and bad information; the latter consisting of noise that arises from inherent estimation error and possible managerial manipulation.

Whether harmonization will actually be achieved is also currently up for debate with many commentators arguing that the same accounting standards can be implemented differently (Kvaal \& Nobes, 2010; Schipper, 2005). In the absence of suitable enforcement mechanisms, real convergence and harmonisation is unlikely to happen (Ball 2006). Cultural, political, and business differences might continue to impose significant obstacles in the progress towards this single global financial communication system (Armstrong, Barth, Jagolinzer, \& Riedl, 2010; Soderstrom \& Sun, 2007) and incentives might continue to dominate the potential effects of accounting standards (Bradshaw \& Miller 2007; Lang, Raedy, \& Wilson 2006). Notwithstanding high quality standards, there is still a risk of having relatively low quality accounting numbers when firms have incentives and opportunities to manipulate their financial statements (Leuz, 2003).

However, whether the various conceptual frameworks could make better financial statements depends on user's demand for qualitative of information. More specific, better financial statements means, these financial statements provided useful information to users to help they make economic decisions. For instance, some stakeholders think reliable information is the information they need. Therefore, they prefer obtain the financial statement evaluated by using historical cost. But historical cost might not relevant for some kind of assets such 
as financial instruments. Or in contrast, since the market price of firm is important to investors, some investors would prefer the value relevant information. So they would prefer the financial report which is measured by fair value. However, according to Whittington, fair value is more relevant to financial statements users than is historical cost, but fair value would also be more subjective to valuate assets and liabilities which means not reliable enough (Whittington, G., June 2008). Someone might argue using mixed measurement system which using fair value, historical cost and deprival value to measure different kinds of assets and liabilities. This might cause mismatch problems where different items in the same set of accounts are measured on a different basis, so that aggregation is misleading, and it also might cause the problem of incomparability and inconsistency. No matter IASB/FASB considering about using which evaluation system to measure assets and liabilities, it cannot meet the users demand very well or in other words, these measurement systems might be lead to subjective income rather than objective one. However, subjective but highly value-relevant information might more helpful to users than reliable but not relevant. Finally, compared with other measurement system, deprival value could provide more information to satisfy user's need. Thus, how to provide information to users is the most significant concern to IASB/FASB's conceptual framework.

\subsection{How to Satisfied User's Need}

Since there is no unique amount of completely objective income to satisfy user's need, whether satisfied users or not depend on how to disclose useful information. As being mention before, the comprehensive income is the changes of equity due to revaluation. Thus, when revaluating assets and liabilities, there are some changes which would cause the changes of profit and loss account but some might not. Therefore, the investors might not know what cause these changes. These changes might due to changes of interest rate; changes of ex ante expected cash flows; credit risk or might due to the changes of ex post expected cash flows. The fact is that investors do not know these kinds of value relevant information which can help them to make the decision. However, IASB/FASB can ask firms to offer a multi-column balance sheet to satisfied user's need in conceptual framework. Firms could disclose Hicks No.1 ex-ante income and ex-post income; the changes of comprehensive income due to credit risk; the changes of capital value result from the changes of interest rate; the changes of capital value due to the expected of future cash flows.

\section{Conclusion}

In conclusion, although FASB/IASB used Hicks No.1 income, there are multiple views of using which measurement systems in financial statement. Since different evaluation system would lead to different amount of income even in the same firm, the conceptual framework project is concentrating on choosing suitable evaluation system and developing regulation that illustrate how the objective of financial reporting and qualitative characteristics of financial statement information apply to the selection of a measurement basis. Regardless of which measurement system, the objective of developing conceptual framework is to help users obtain useful information from financial statements. Thus, when developing conceptual framework, how to disclose information in financial report should be the important part and FASB/IASB should take it seriously.

\section{References}

Armstrong, C., Barth, M. E., Jagolinzer, A., \& Riedl, E. J. (2010). Market reaction to events surrounding the adoption of IFRS in Europe. The Accounting Review, 85(1), 31-61. http://dx.doi.org/10.2308/accr.2010.85.1.31

Ball, R. (2006). IFRS: Pros and cons for investors. Accounting and Business Research, 5-27. http://dx.doi.org/10.1080/00014788.2006.9730040

Beaver, W. H., \& Demski, J. S. (1979). The nature of income measurement. The Accounting Review, LIV, 1979.

Bradshaw, M., \& Miller, G. S. (2007). Will harmonizing accounting standards really harmonize accounting? Evidence from non-U.S. firms adopting U.S. GAAP. Working paper, Harvard Business School.

Bromwich, M. (1992). Financial reporting: Information and capital markets. London: Pitman.

Choi, F. D. S., \& Meek, G. (2005). International accounting (5th ed.). Prentice-Hall.

FASB/IASB Revisiting the Concepts. (May 2005). Retrieved from http://www.fasb.org/project/communications_paper.pdf

Graeme, D., Andrew, L., Geoff, W., Richard, M., \& Mary, B. (2009). Wanted: Foundations for measurement in accounting. Working paper: Eaa Symposium, Tampere, 18 Oct., 2009.

Hicks, J. R. (1946). Income=Chapter XIV of value and capital (2nd ed.). Oxford: Clarendon Press. 
Kaldor, N. (1955). The concept of income in economic theory.

Kvaal, E., \& Nobes, C. W. (2010). International differences in IFRS policy choice. Accounting and Business Research, 40(2), 173-187. http://dx.doi.org/10.1080/00014788.2010.9663390

Lang, M., Raedy, J., \& Wilson, W. (2006). Earnings management and cross listing: Are reconciled earnings comparable to U.S. earnings? Journal of Accounting and Economics, 42(1/2), 255-283. http://dx.doi.org/10.1016/j.jacceco.2006.04.005

Leuz, C. (2003). IAS versus U.S. GAAP: Information-asymmetry based evidence from Germany's new market. Journal of Accounting Research, 41(3), 445-472. http://dx.doi.org/10.1111/j.1475-679X.2003.00111.x

Peasnell, K. (1982). Accounting and Business Research Autumn, 243-256. http://dx.doi.org/10.1080/00014788.1982.9728816

Penman, S. (2007). Financial reporting quality: is fair value a plus or a minus? Accounting and Business Research Special Issue: International Accounting Policy Forum, 33-44.

Quigley, J. (2007). Deloitte and Touche World meeting, Berlin, Germany.

Schipper, K. (2005). The introduction of IAS in Europe: Implications for international convergence. European Accounting Review, 14, 101-126. http://dx.doi.org/10.1080/0963818042000338013

Soderstrom, N., \& Sun, K. (2007). IFRS adoption and accounting quality: A review. European Accounting Review, 16, 675-702. http://dx.doi.org/10.1080/09638180701706732

Sundem, G. L. (2007). A note on the information perspective and the conceptual framework. In R. Antle, F. Gjesdal, \& P. J. Liang (Eds.), Essays in accounting theory in Honour of Joel S. Demski (pp. 285-293). New York: Springer. http://dx.doi.org/10.1007/978-0-387-30399-4_13

UK and International GAAP. (1997). Ernst \& Young (5th ed.). Palgrave Macmillan.

Whittington, G. (2008). Fair value and the IASB/FASB conceptual framework project: An alternative view. Abacus, 44(2), 139-168. http://dx.doi.org/10.1111/j.1467-6281.2008.00255.x

\section{Copyrights}

Copyright for this article is retained by the author(s), with first publication rights granted to the journal.

This is an open-access article distributed under the terms and conditions of the Creative Commons Attribution license (http://creativecommons.org/licenses/by/3.0/). 